\title{
The European Parliament's Diplomacy - a Tool for Projecting EU Power in Times of Crisis? The Case of the Cox-Kwasniewski Mission*
}

\author{
CRISTIAN NITOIU ${ }^{1}$ and MONIKA SUS ${ }^{2}$ \\ 'LSE IDEAS, London School of Economics. ${ }^{2}$ Hertie School of Governance
}

\begin{abstract}
The aim of this paper is to shed light on the way the European Parliament's diplomacy affects EU power, particularly during times of crisis. The analysis is focused on the Cox-Kwasniewski mission that the Parliament sent to Ukraine in 2012-13. Based on interviews and existing literature, we discuss the genesis and the development of the mission and then evaluate its impact. We argue that the mission with time became a key diplomatic instrument and enabled EU power projection by giving momentum to the promotion of the EU's approach towards Ukraine, which was already wavering due to the deadlock over the Association Agreement between Kyiv and Brussels and then due to President Yanukovych's refusal to sign the agreement.
\end{abstract}

Keywords: Parliamentary diplomacy; Cox-Kwasniewski mission; diplomatic innovation; Ukraine

\section{Introduction}

Since the mid-1990s the European Parliament (EP) has aimed to increase its ability to shape the European Union's (EU) foreign policy and become an actor in its own right. It has done this in three main ways: firstly, the EP has gradually constructed an original type of parliamentary diplomacy which draws on its strengths (Fiott, 2011); secondly, it has mediated between (and bargained with) other EU institutions constructing in this way a distinct identity (Servent, 2015); thirdly, it has constantly advocated for more legal competences to be allotted to it by the EU's treaties. The latter means has recently registered noticeable results, whereby the adoption of the Lisbon treaty recognised the democratic deficit of the EU (and its foreign policy) and highlighted the EP's role in ensuring democratic legitimacy (Stavridis and Irrera, 2015). Hence, the EP has gained various competences in foreign policy with the adoption of the Lisbon treaty, even though it is still far behind the power of national parliaments. The treaty has extended decision-making to various policy areas such as: energy, trade, border checks, human trafficking and immigration, common visa policy, ratifying agreements with EU's neighbours, various aspects of cross-border crime, or more broadly the former third pillar of Justice and Home Affairs.

While the effects of the Lisbon treaty on the competences of the EP in foreign policy have been quite thoroughly researched, the same cannot be said about the EP's own diplomacy. We aim to shed light on the way the EP's diplomacy affects EU power, particularly during times of external crisis. In line with the rationale of the Special Issue we are inter-

\footnotetext{
*The authors would like to thank the anonymous referees for their comments and wish to acknowledge the financial support of the National Research Council for this publication (along the project decision: DEC-2013/09/B/HS5/01356). Moreover, the research for this article was supported by the Dahrendorf Forum, a joint initiative by the HertieSchool of Governance, LSE, and Stiftung Mercator.
} 
ested in the way the EP's diplomacy enabled or constrained the ability of the EU to project its power in the background of the Ukraine crisis. The EP's diplomacy is seen here as an element in the EU's toolbox used for promoting its goals in its relations with Kyiv and managing the crisis in Ukraine (that is, the projection of EU power). Hence, by focusing on the EP we aim to shed light on a means of EU power projection which is rarely discussed in the literature, but one which, as we show, played a key role in shaping the EU's engagement with Kyiv in the build-up to the Ukraine crisis.

Research on this topic is still in its infancy, as the EP's diplomacy is a rather fluid and multifaceted concept or process (Fiott, 2011; Stavridis and Irrera, 2015; Weisglas and de Boer, 2007). We define parliamentary diplomacy as a complementary tool to traditional diplomacy (driven by institutions holding executive power) which captures the broader political role of parliaments in the formulation and implementation of foreign policy. The main tools used by the EP in order to bolster its parliamentary diplomacy include: the activity of EP delegations in neighbourhood states, official visits, sending messages through reports and resolutions, hosting delegations, organizing informal or fact-finding missions such as election observatory missions, establishing parliamentary co-operation with other legislative bodies or the activities of EP party groups. In this article we focus on the Cox-Kwasniewski mission that the EP sent to Ukraine in 2012-13, which is seen as a good testing ground for the way the EP's parliamentary diplomacy shapes and constitutes EU power in times of crisis. The work of the mission was facilitated by the minor crisis in relations between the EU and Ukraine which started with the alienation of Russia after the adoption of the Eastern Partnership (EaP) and the election of Victor Yanukovych as President of Ukraine in early 2010. What makes this case interesting for the study of EU power projection during external crises is the fact that Pat Cox and Aleksander Kwasniewski had initially a limited mandate of observing the trial of former Ukrainian Prime Minister (PM) Yulia Tymoshenko in the summer of 2012 and quickly managed to expand its remit to other policy issues. Moreover, the Member States and the European Commission (EC) gradually recognized the role of the mission for the EU in Ukraine as a key diplomatic tool. The mission managed to give momentum to the promotion of the EU's approach towards Ukraine, which was already wavering.

The article presents a question-driven approach which focuses on the puzzle surrounding the way the Cox-Kwasniewski mission affected EU power projection in Ukraine. We argue that the impact of the mission was between marginal and considerable as it managed to convince the Ukrainian government to adopt a series of reforms and played a key role in restarting the DCFTA negotiations, but ultimately failed to fulfil its mandate or more broadly secure Ukraine's signature of the Association Agreement (AA) at the 2013 Vilnius summit. By applying a question-driven approach the article is able to provide a more complex picture of the way the mission affected the EU's external projection of power in Ukraine. It also allows us to focus in more detail on the factors which led to the proposal for the mission, its implementation and impact. Rather than focusing on a narrow theoretical framework or method, question-driven research more generally allows scholars to employ a pluralist approach to uncovering complex and multifaceted puzzles (Fierke and Jorgensen, 2015; Griffiths, 2007).

We procced in two steps. Firstly, we aim to explain and trace why the EP proposed the mission, and how the Commission and the Member States came to recognize the work of 
the envoys as a primary tool of EU foreign policy in Ukraine. We conclude that the mission enabled the EP to have a more salient role in setting the agenda of the EU's relations with Ukraine. Nevertheless, when the crisis transformed into one of EU-Russia relations and began to concern the security of the whole continent, the work of the mission (and the EP's diplomacy) became less relevant and moved into the background. The mission also enhanced co-ordination between the EP, the Commission and the Member States. This happened both in Brussels and also on the ground in Ukraine, where the mission cooperated effectively with Member States' embassies and the EU delegation. ${ }^{1}$ Moreover, the mission enabled the EU to become more resourceful and innovative in projecting its power in Ukraine at a time of stalemate in relations between Kyiv and Brussels.

Secondly, we evaluate the external impact of the mission as a tool for exercising EU power externally drawing on the categories developed by Roy Ginsberg (2001). In order to examine the short-term impact of the Cox-Kwasniewski mission we draw on Ginsberg's framework for measuring the external impact of EU foreign policy (2001, p. 52-54). Based on his approach, we consider four levels of political influence of the EP's mission towards Ukraine: insignificant impact - the mission was not successful and did not manage to lead to the adoption of reforms or political change; marginal political impact - the mission did not manage to bring about change in Ukraine's political system, but was able to convince the government to implement a series of limited reforms; considerable political impact - the envoys succeeded in influencing broader changes in policies and reforms without achieving all of their initial goals; and significant political impact - the EP's mission was the main actor responsible for salient political change in Ukraine. We find that even though it did not achieve its primary goal (the release of Tymoshenko) and was seen by some as wasteful or lacking accountability, it was evaluated by the EP, the Commission and the Member States as an effective diplomatic tool. On the other hand, we argue that even though its political impact was not fully tangible (or considerable) the mission played a crucial role in mediating between the governing elites and opposition in Ukraine, but also between the Commission and Ukraine in the negotiation of the Association Agreement. Moreover, Cox and Kwasniewski's efforts did lead in the end to the release of a few political prisoners, the adoption of new reforms for improving detention conditions in Ukraine and highlighting the commitment of the EU towards supporting Ukraine's European aspirations. We also find that the mission was a diplomatic innovation well suited for dealing with the domestic context in Kyiv of the time, but also in terms of the interests of the Member States or power relations between the EP and Commission. Hence, even though the mission might prove hard to replicate, it proved to be a sensible tool for dealing with the crisis in EU-Ukraine relations in 2012-13.

This article is structured as follows. The next two sections focus on the two research aims outlined earlier: a) to analyze why the EP proposed the mission, and how it became recognized by the Member States and the Commission as a primary tool of EU foreign policy in Ukraine; and b) to evaluate the mission's short-term impact. In the conclusion we then return to the broader research question of the article: namely, how the mission (and the EP's diplomacy) affected EU power projection in Ukraine in the short to medium term.

\footnotetext{
${ }^{1}$ Interview 4; Interview 5.
} 
With regard to data and sources, our paper is primarily based on documents of the EP (and the mission itself) and of other EU institutions as well as on secondary literature on EU-Ukraine relations and on parliamentary diplomacy. In order to get better insight into the mission we also conducted anonymous interviews with officials from EU institutions who were involved in the activities of the mission and with experts on Ukraine. Moreover, we had the opportunity to pose questions about the mission to Aleksander Kwasniewski and to get his take on the course of events.

\section{Explaining the Genesis and Development of the Mission}

In order to understand the way in which the development of the Cox-Kwasniewski mission affected EU power in Ukraine we examine a series of factors. Firstly, we focus on external factors and show that external events (the crisis in relations between the EU and Ukraine) offered the perfect context for the mission to emerge and develop. Secondly, we discuss to what extent the demands from external actors (such as Ukraine) for mediation pave the way for setting up the mission and its functioning. Then we turn to the internal factors and argue that the EP's aspiration to have a more salient role in shaping EU foreign policy was the main rationale for proposing the mission. Finally, we show that the mission was facilitated by the fact that it incurred low material costs for the EU, but also in terms of altering power relations among EU institutions. Out of the four we find that the emergence and persistence of the crisis in EU-Ukraine relations was the most important factor for the development of the mission.

\subsection{External Events: The Crisis in EU-Ukraine Relations}

While the Ukraine crisis made international headlines with the protests in Maidan square and the annexation of Crimea in March 2014, the crisis in relations between the EU and Ukraine has its roots much earlier. This moment can be traced back to the GeorgianRussian war of 2008 and the launch of the EaP. Neither event directly influenced EUUkraine relations as much as they affected relations between Moscow and Brussels, and more importantly the way the Kremlin sought to reposition itself in the post-Soviet space (Freire, 2014; Haukkala, 2010). The war in Georgia showed Russia that the EU was not willing to intervene forcefully in order to back up the promotion of its norms and values in the Eastern neighbourhood (Sinkkonen, 2011). European policy-makers understood that Russia was mostly interested in preserving the status quo of the post-Soviet space in terms of security, and that leaders in the Kremlin did not oppose the EU's technocratic approach (largely de-politicized low-key sector-driven co-operation) in the region. However, the launch of the EaP and the staunch anti-Russian approach of the new Central and Eastern European members made Moscow more conscious that, through its policies, the EU was pursuing a geopolitical agenda in the Eastern neighbourhood. In this context, the Kremlin intensified its pressure on the post-Soviet states through energy prices, and sought to support local elites that would allow it to influence (if not control) the domestic politics of the countries in the region (Babayan, 2015). The EU did not really take Russia's concerns and actions seriously. The crisis in EU-Ukraine relations started to become slightly evident when pro-Russian Yanukovych was elected as President in February 2010. Russia hoped to have a key player in Ukraine that 
would help it counter the EU's policies. Moreover, the regime of Yanukovych proved to be corrupt and leaning towards authoritarianism, which posed increasing difficulties for the projection of EU power in Ukraine (Samokhvalov, 2015). Nevertheless, in this phase the crisis in EU-Ukraine relations was rather weak and affected the EU's ability to project its power only indirectly. The EaP, on the one hand, offered Ukraine the prospect of enhanced economic co-operation through the signing of the AA and Deep and Comprehensive Free Trade Agreement (DCFTA), which gave Brussels a certain measure of leverage over Yanukovych. On the other hand, Russia had serious concerns about the EU's geopolitical moves in the post-Soviet space, but the prospect of an equal strategic partnership between Moscow and Brussels together with EU support for Russian membership in the World Trade Organisation (WTO) were enough to keep tensions hidden (Casier, 2013).

As Yanukovych's presidential term progressed, problems with the rule of law and the EU's ability to promote its policies in Ukraine became more and more apparent. High levels of corruption, misappropriation of public (and EU) funds and the use of the justice system by the government in order to target the opposition were seen as the main obstacles to the projection of EU power in Ukraine (Wilson, 2014). In the background these developments were supported by Moscow, which tried more or less covertly to hinder the EU's policies in Ukraine (Delcour and Wolczuk, 2015; Smith, 2015). Moreover, Russia announced plans for the establishment of a Eurasian Economic Space and the Eurasian Economic Union (EEU), hoping that Kyiv would be one of its key pillars. The trial of former PM Tymoshenko which started in late 2010 put in doubt the independence of the justice system and threatened to derail the negotiations of the AA. This paved the way for the EP to propose the Cox-Kwasniewski mission as a way of supplementing the EU's efforts in Ukraine and putting the AA negotiations back on track.

The Cox-Kwasniewski mission can be seen as part of the EP's efforts to have a more salient role in EU foreign policy, and is a prime example of parliamentary diplomacy. These types of diplomatic innovations consisting of missions led by high-profile individuals have been used by international organizations in order to provide mediation in times of crisis, for example the Vance and Owen mission in Bosnia. The EU itself used highprofile missions in relations with Ukraine before. This happened in 2004 during the Orange Revolution, which was sparked by protests due to electoral fraud during the presidential elections. At that time, Javier Solana, the former High Representative for CFSP (Common Foreign and Security Policy) and Kwasniewski, the Polish President of the time, facilitated the mediation in the Yanukovych-Yushchenko standoff. The duo was an $A D h O c$ arrangement and an outcome of Polish self-initiative and the EU's resistance to engaging at a higher level. ${ }^{2}$ Although there were other politicians involved in the mediation, such as Lithuania's President Valdas Adamkus or Jan. Kubis, OSCE Secretary General, it was Kwasniewski and Solana who played a crucial role in facilitating the agreement. They convinced Ukrainian elites to support a rerun of the presidential elections. Their mission turned out to be a credible and successful instrument to pursue the EU's goals in Ukraine (Pifer, 2007).

The Cox-Kwasniewski mission was originally planned for two weeks in order to observe former PM Tymoshenko's trial until it was supposed to end. However, the trial

\footnotetext{
${ }^{2}$ Interview 1.
} 
dragged on due to political reasons and the mission was subsequently prolonged. Tymoshenko's trial was seen as testimony to Ukraine's low performance in the area of rule of law and the overall quality of the justice system. It brought particularly into question the independence of the justice system from the government, its low professional standards and lack of respect for human rights, as Tymoshenko was denied adequate medical treatment in prison. The mission started on 11 June 2012 and in the end lasted for 18 months. The envoys visited Ukraine 27 times. Initially they only attended court hearings on the cases against Tymoshenko, Yuriy Lutsenko, the former minister of interior, Valeriy Ivashchenko, the former minister of defence, and Heorhiy Filipchuk, former minister of the environment, and evaluated trial documents raising doubts regarding the standards of the justice process (European Parliament, 2013). However, the mission broadened its scope by criticizing the Ukrainian government for the state of the penitentiary system. As a 'privileged channel of communication' (European Parliament Monitoring Mission to Ukraine, 2013a), the envoys were free to speak on different levels - parliamentarian, governmental, judicial - with the ruling elites and with the opposition. They attended court hearings on the cases of selective justice, met with Yanukovych 17 times and 25 times with the PM Azarov and spoke 21 times with the opposition, the representatives from the non-governmental organizations and imprisoned politicians as well as their lawyers (Cox, 2014). They also visited Tymoshenko in Kharkiv hospital several times in order to check if adequate medical care was provided to her.

In the spring of 2013 the EU increased its pressure on Kyiv to make progress in adopting reforms so that the AA could be signed later that year. The mission also intensified its work in Ukraine, primarily highlighting the deficiencies in the country's justice system (European Parliament Monitoring Mission to Ukraine, 2013a). Russia became increasingly aware of the EU's determination to sign the AA and (from the Kremlin's perspective) to bring Kyiv irrevocably under Europe's sphere of influence. Moreover, signing the agreement would have made the prospect of Kyiv joining the EEU virtually impossible, as the integration projects were mutually exclusive. As Ukraine was one of the key pieces in the designing of the EEU, Russia increased its pressure on Yanukovych not to sign the AA, by offering loans and preferential energy prices, but also threatening him. In turn, Yanukovych adopted a less coherent stance towards the AA, and reverted to the traditional multi-vector foreign policy that most of the post-Soviet states applied during the 1990s and early 2000s (Gnedina, 2015).

The EU was unresponsive to Russia's pressure on Yanukovych and thus caught by surprise by Ukraine's decision not to sign the AA at the Vilnius summit in November 2014. The envoys released its final report a few weeks before the summit, arguing that Kyiv had made progress in the area of rule of law, but still showed deficiencies in the areas of corruption and the independence of the justice system (European Parliament Monitoring Mission to Ukraine, 2013c). During the Maidan protests, the EU focused on mediating between Yanukovych and the opposition. Various delegations of MEPs and European politicians and minsters of foreign affairs were on the ground in order to highlight the European support for the agenda of the protestors and negotiate a settlement with the President. As the crisis became more severe, with Yanukovych fleeing to Russia, the annexation of Crimea and the emergence of Russian-backed separatists in Eastern Ukraine, the focus of the EU's approach towards Ukraine moved to high-level diplomacy. German Chancellor Merkel and French President Hollande took the spotlight in an effort to alleviate the crisis 
and mediate between Ukraine and Russia. Moreover, their leadership managed to secure consensus among the Member States on a set of sanctions against Russia, a level of agreement which would have seemed almost inconceivable before the crisis (David et al., 2013).

However, while the crisis in relations between the EU and Ukraine transformed into a broader crisis of security on the European continent, the EU still continued in the background to support the promotion of its regulations and norms in Ukraine through low-level diplomacy - but more cautiously than before late 2013. Dozens of experts and delegations from the Commission and the EP were sent to Kyiv from the spring of 2014 in order to help the new government embark on a series of structural reforms meant to further its process of European integration. Although both parts of the AA were signed - the political part on 21 March and the economic one on 23 June 2014 - Ukraine still needed wide-ranging reforms to fulfil commitments to co-operate and to converge policy areas, legislation and regulations with the EU. In July 2014, the EU Advisory Mission for Civilian Security Sector Reform Ukraine was established within the framework of the CSDP (Common Security and Defence Policy). The goal of the mission is to support reforms indispensable for the implementation of the AA. ${ }^{3}$ At the same time the President of the EC brought into being a 'Ukraine Support Group'. Its task is to ensure that technical support provided by the Commission in the form of advice, expertise and financial cooperation is focused and concentrated according to the Association Agenda. ${ }^{4}$

Although these diplomatic efforts operate rather in the background and complemented the high-level efforts of Germany and France, the EU drew on the work of the CoxKwasniewski mission, using open channels of communication and established contacts. Furthermore, the former envoy became a chief of a new EP mission aimed at the assessment of the needs of the Ukrainian parliament - Verkhovna Rada - in view of its reform. ${ }^{5}$ According to the memorandum of understanding between the Ukrainian and the European parliaments, the mission shall establish a roadmap for improvements related to the institutional capability of Verkhovna Rada. It is one of the footprints of the parliamentary dialogue between Kyiv and Brussels which has been active since $2014 .^{6}$

\subsection{Demands from External Actors}

The second external factor was a demand on the part of Ukraine for an independent mediator that would help to advance the negotiations for the AA, as domestic pressure to cooperate with the EU was increasing. Hence, Kyiv saw the mission as more of a mediator between its own interests and the agenda of the Commission. In turn, the mission was not perceived to be a real threat by the Ukrainian government as it did not have any formal powers, and would not interfere in terms of content in the negotiation of the AA. In this sense, Kwasniewski argues that the idea for the mission originated more from the Ukrainian PM than the EP. ${ }^{7}$ The President of the EP Martin Schulz jumped on the opportunity in order to break the deadlock between Kyiv and Brussels. Two EEAS officials have also confirmed this opinion. ${ }^{8}$ The mission had a certain degree of independence

\footnotetext{
${ }^{3}$ See: http://www.eeas.europa.eu/csdp/missions-and-operations/euam-ukraine/index_en.htm.

${ }^{4}$ See: http://ec.europa.eu/enlargement/neighbourhood/countries/ukraine/sgua/index_en.htm.

5 See: http://www.unian.info/politics/1119943-ex-president-of-european-parliament-leads-mission-to-reform-rada.html.

6 See: http://ukraine-eu.mfa.gov.ua/en/ukraine-eu/parliamentary.

7 Interview 4.

${ }^{8}$ Interview 3 ; Interview 5.
} 
from the EP as neither of the envoys was actually accountable to the Parliament, or a member of it. Moreover, the inclusion of Cox reassured Ukraine of the impartiality of the mission, as Kwasniewski had been involved in Ukraine for many years. In comparison to the former Polish president, Cox saw their role in a more detached and slightly less ambitious manner. Cox was more committed to the initial goal of monitoring Tymoshenko's trial and the state of prisoners than influencing the negotiations for the AA: 'Our purpose was not to substitute for legal expertise but rather to draw on its analysis and seek to channel its reforming capacity into deliverable political outcomes' (Cox, 2014, p. 6). At the same time, the envoy seemed to be surprised with the development and repositioning of the mission in terms of its goal and perceptions by other actors: 'The mission later morphed into something much larger as we became a key point of exchange between not only Brussels and Kyiv, but also between the Ukrainian government and the opposition, who basically were not speaking to each other at the time but would each speak to us' (Adekoya, 2014).

\subsection{The EP's Desire to Have a More Salient Role in EU Foreign Policy}

Turning to the internal factors, we start with an examination of the EP's desire to become a more salient player within EU foreign relations. With the adoption of the Lisbon treaty the EP gained the ability to co-legislate in a series of areas which are part of the EU's policy towards the post-Soviet space (and Ukraine for that matter), such as border checks or human trafficking and immigration. However, in terms of allowing the EP greater agenda-setting power in EU foreign policy or on the way the EU's policies are implemented and represented in third countries, the Lisbon treaty did not add anything significant (Stavridis and Irrera, 2015). In this sense, the EP has been developing over recent decades a distinct type of parliamentary diplomacy that would allow it to have a more autonomous role in international relations. For example, the EP was involved in presidential elections in Ukraine in 2010 and 2014, where it sent observation missions. Moreover, the EP has a standing delegation to the EU-Ukraine Parliamentary Cooperation, which meets twice a year with Ukrainian MPs. Statements by the body tend to be joint; however, throughout Yanukovych's term as President they frequently highlighted the EP's concerns with the declining democratic standards in Ukraine. In turn, the EURONEST Parliamentary Assembly ${ }^{9}$ has been largely ineffective in terms of solving the crisis in EU-Ukraine relations, due to the fact that its statements did not refer directly to the decreasing democratic standards in Ukraine. ${ }^{10}$ At the same time, during the Maidan protests the EP dispatched two $A D$ hoc delegations (January-February 2014). They acted as fact-finding missions and sought to interact with actors from the government, opposition and civil society.

Against this backdrop, the Cox-Kwasniewski mission was the most salient tool of parliamentary diplomacy and a sign of a particularly active EP approach towards Ukraine. The idea to replicate the success of the 2004 mission in order to mediate the deepening crisis in EU-Ukraine relations became relevant in 2012. ${ }^{11}$ Hence, the EP decided to

\footnotetext{
${ }^{9}$ The Euronest Parliamentary Assembly is an interparliamentary group set up under the EaP which reunites members of the representatives of parliaments from the EaP countries.

${ }^{10}$ The meeting documents of the Euronest Parliamentary Assembly are available here: http://www.europarl.europa.eu/ meetdocs/2009_2014/organes/nest/nest_7leg_meetinglist.htm.

${ }^{11}$ Interview 1.
} 
make use of the experience of the previous mission and to provide further drive to the EU's agenda in Ukraine, which was at that time in a deep impasse. As presented in detail in the previous section, Schulz and Azarov set up the new special mission to observe the approaching appeal process of Tymoshenko by a joint decision. The EP proposed for this task internationally recognized personalities who were 'enjoying respect both in the EU and in Ukraine' (Rettman, 2012). Kwasniewski, due to his experience and regional competences, was an obvious candidate. Cox, as a former president of the EP, was asked to join the mission as a voice from a country which was not directly interested in the politics of the Eastern neighbourhood and as a former representative of the EU's institutional level. It was Kwasniewski himself who asked Schulz for a counterpart, to balance out the mission, someone with no significant previous experience of dealing with Ukraine and from the West. The constellation of that mission was however very different from the previous one. In 2004 Kwasniewski was a serving Polish president and Solana represented the line of 25 Member Atates as the High Representative. By contrast, the new mission was set up with two individuals who did not hold a position of power - the exPresident of Poland, who had not been politically active since 2008, and the ex-President of the EP, whose political career ended in 2004 when he stopped serving in that position. Therefore, the credibility of the special envoys was not as strong as was the case with the 2004 mission, but had the potential to increase the EP's role in the region by unfreezing EU-Ukraine relations. ${ }^{12}$

While both envoys were generally seen to be independent from the EP, in practical terms the parliament had a lot of influence on the technical work and agenda of the mission. The EP paid for the logistical support for the mission and kept a close eye on its finances. Moreover, Cox and Kwasniewski's work was assisted by a legal expert and two policy advisors from the EP Secretariat and a member of Schulz's cabinet. ${ }^{13}$ The mission reported to the leaders of the EP's political groups which form the Conference of Presidents, with which they met both formally and informally every two to three months. Cox and Kwasniewski also had regular meetings with the members of the EP Foreign Affairs Committee, with which they shared information and relied on their advice. There were divisions in the parliament regarding the utility of the mission, but these voices were only marginal - represented primarily by the Greens. ${ }^{14}$

The Commission and the Member States were rather uneasy at first with the idea of the mission but gradually came to view it as an effective tool of EU foreign policy (Petrova, 2014). However, a few months into the work of the mission, the EU Foreign Affairs Council on 10 December 2012 praised and welcomed the mission's entrepreneurship and the way it was contributing to the EU's foreign policy. The mission was made even more salient by the fact that the EU linked directly improving rule of law standards to the negotiation of the AA (Council of the European Union, 2012). This in turn made the Cox-Kwasniewski work an integral part of the EU's approach towards Ukraine. Besides its work on the Tymoshenko case, the mission had a measure of impact as it led to the release of a series of other prisoners who were thought to have been incarcerated for political reasons. The mission also focused on the human rights aspects of the Ukrainian

\footnotetext{
${ }^{12}$ Interview 1.

${ }^{13}$ Interview 2.

${ }^{14}$ Interview 4.
} 
system, constantly calling on the government for improvements. Thus, the Commission started to recognize the added value of the mission. In this sense, the commissioners involved in the negotiation - particularly Füle (responsible for the European Neighbourhood Policy) and de Gucht (responsible for EU trade) - had constant contact with the mission and viewed it as an integral part of the Commission's work. Also the Council acknowledged the high degree of usefulness of the mission. For example, in the conclusions of the Foreign Affairs Council meeting, they recognized the mission as an added value for the EU's external action: 'The Council commends the efforts undertaken by the European Parliament's monitoring mission to Ukraine headed by former Presidents Cox and Kwasniewski. The Council expects the authorities to address the cases of politically motivated convictions without delay as well as to take further steps to reform the judiciary to prevent any recurrence' (Council of the European Union, 2012, p. 13). Furthermore, the legitimacy and reputation of the mission was also signalled by the fact that the mission's final recommendation that Ukraine had to continue working on solving the issues of selective justice (subject to political pressure) was included in the conclusions of the Foreign Affairs Council: 'EU High Representative emphasised that the main outstanding case of selective justice needed to be addressed and that the Council continued to support the efforts of the European Parliament monitoring mission to this end' (Council of the European Union, 2013). What this highlights is that even though at first the mission was primarily an initiative by the EP in order to become more visible in EU foreign policy by unfreezing relations with Ukraine, the Commission and the Council quickly embraced it.

\subsection{The Low Material and Political Costs of the Mission}

Finally, an important reason that might explain the support for diplomatic innovations such as the Cox-Kwasniewski mission are their low material and political costs. The relative success of the 2004 mission set out the blueprint for the way the EP could engage more substantially in EU foreign policy. The aim of the undertaking was achieved and the costs incurred were small. Also the costs for establishing the Cox-Kwasniewski mission were minimal in financial terms as it was assisted by a legal expert and two policy advisors from the EP Secretariat and a member of Schulz's cabinet. Additionally, both envoys worked on a pro bono publico basis for the mission, investing their time in trips to Ukraine and Brussels (Cox, 2014). But it was also the case with political costs in terms of power relations with other EU institutions and the Member States, as the mission had a certain degree of independence from the EP. Neither of the envoys was actually accountable to the Parliament, or a member of it - which did not pose a direct challenge to power relations in EU foreign policy. Moreover, while the decision to mediate in Ukraine in 2004 was discussed by all Member States and the EU officials, the new mission was rather a unilateral decision of Schulz in co-operation with Azarov. The European External Action Service (EEAS) and the Commission, as well as the Member States, were only briefly informed about this undertaking and accepted it since other instruments at the EU's disposal seemed to be insufficient to solve the deadlock in the bilateral relationship with Kyiv (Rettman, 2012). Consequently, in summer 2012 the mission had neither a strong EU backing nor did it represent the common position of the Member States. The mission managed to gather broader support among a wide range of EU actors despite this, 
as presented in the previous section. The Member States and Commission fully embraced it only after Cox and Kwasniewski proved the usefulness of their efforts for promoting the EU's approach in an increasingly hostile external context of relations with Kyiv. Together with the potential for the mission to advance negotiations with Kyiv, the Commission and the Member States supported it because it incurred low material and political costs. The potential of the mission became particularly evident after the release of Lutsenko on 7 April 2013. Lady Ashton and Commissioner Füle emphasized in a joint statement this achievement by mentioning the 'important contribution the European Parliament's monitoring mission to Ukraine headed by former Presidents Cox and Kwasniewski has made in this context' (European Union, 2013). In practice this level of support translated into practical assistance from the embassies of the Member States and the EU delegation in Kyiv. In particular the Commission and the EEAS recognized the added value of the mission, since the two envoys debriefed the EU delegation in Kyiv 16 times on the progress of the trials and the reform process. Because the EU delegation's staff was similarly restrained in the communication with Ukrainian elites as Brussels institutions, the mission was a source of information out of the public view which could not have been gained in any other way. Mutually, Cox and Kwasniewski benefited from the goodwill of the Commission and some of the Member States (particularly those interested in Ukraine, such as Germany, Poland or Lithuania), which gave them access to a large pool of information and expertise. ${ }^{15}$

\section{Evaluating the Impact of the Mission}

Following the framework formulated by Ginsberg (2001, pp. 52-54), we examined the short-term impact of the Cox-Kwasniewski mission and showed that the impact of the mission was between marginal and considerable. The envoys managed to convince the Ukrainian government to adopt a series of reforms and played a key role in restarting the DCFTA negotiations, but ultimately failed to fulfil its mandate or more broadly secure Ukraine's signature of the AA at the 2013 Vilnius summit.

The initial mandate of the Cox-Kwasniewski mission was to address the politically motivated, high-profile criminal cases resulting in the imprisonment of Tymoshenko and three ministers of her government. Keeping the main goal in mind, the envoys first tried to establish lines of communication and to open a dialogue with the government in Kyiv in particular, but also with opposition and civil society groups. They engaged in this process without interfering in political and technical debates and interests of one or another side, trying at a minimum to improve the situation of the imprisoned former politicians or to achieve their release at best. The regular and intensive dialogue initiated by Cox and Kwasniewski with Ukrainian elites on different levels, primarily behind closed doors, was partly successful. Progress of the Ukrainian government on the three defined areas was expected by May 2013 and indeed in the first half of that year, elites in Kyiv made several efforts to accomplish the conditions set by the EU. In the mission update the envoys presented to the European Parliament in April 2013, they indicated the first advancements of Kyiv such as the release of three prominent political prisoners: Ivashchenko was set free on 14 August 2012 and Lutsenko and Filipchuk were pardoned

${ }^{15}$ Interview 2; Interview 4. 
on 7 April 2013. Particularly the release of Lutsenko was recognized as a success of the diplomatic mission. Moreover, the EP's envoys welcomed the entering into force of the new Criminal Procedure Code, endorsed by the Venice Commission and expected to reduce significantly the number of pre-trial detainees (Cox, 2014; European Parliament Monitoring Mission to Ukraine, 2013a). At the same time, the duo also pointed out several shortcomings in achieving the international standards within the judicial system, such as the Soviet-style prosecution service, which had to be improved. Since then, the mission undertook eight additional visits to Ukraine and made intensive efforts in encouraging the authorities and the opposition to work out solutions in order to meet the EU's expectations in the key areas. The final report of the mission that was issued in October 2013 stressed further progress of the Ukrainian authorities in improving the electoral legislation and reforming judiciary (European Parliament Monitoring Mission to Ukraine, 2013c).

However, the two envoys failed in facilitating a mutually acceptable solution to the Tymoshenko case, which stood in the way of the Council's decision on the potential signing of the AA. Although her release was not a formal condition for the AA, some Member States such as Germany insisted that charges against her must be abandoned before the agreement could be signed. As Kwasniewski admitted in an interview for 'Der Spiegel', there were three options on the table: a release of the former PM, a partial pardon and a reduction of prison time, or the ability to leave the country for medical treatment (Puhl and Neef, 2013). The latter was the most desired one as it would have opened the way for the agreement and allowed Yanukovych not to lose face. Hoping that this issue could be solved, the EP's Conference of Presidents decided to extend the mandate of the mission until the Vilnius Summit. At that time there was no serious sign of declining of the AA by Ukraine, as the two specific and one potential proposals for the laws required to achieve compliance were on the agenda of the Verkhovna Rada. The two specific laws were on the public prosecutor's office and on the law on parliamentary elections. They both were passed in the first reading and the final one was expected shortly before the summit. The expectations were high: 'These reforms, if conducted and implemented fully and in line with European standards, could significantly change the political and legal landscape in Ukraine' (European Parliament Monitoring Mission to Ukraine, 2013b). The potential proposal concerned the law on medical treatment abroad, which would pave the way for the expected solution of the Tymoshenko case. Jacek SaryuszWolski, European People's Party (EPP) Vice-President, made the EP's position on that matter clear by saying that 'time is out and the window of opportunity which is the November EaP summit in Vilnius, is closing fast. Ukraine has to immediately make a real and credible progress. If not, the EU will not sign an agreement based on a purely rhetoric exercise' (Gotev, 2013). However, Tymoshenko was not released and Yanukovych pressed the pause button on the AA. ${ }^{16}$ Although the envoys were talking to the President up to the very last moment about the signing of the document, his decision came as a surprise. It became evident that the Ukrainian President used the dialogue with the EU to get more out of Russia: 'Kyiv constantly switches from one partner to another, without keeping the other side happy while it deals with the other pole. It is also far too obvious in using one side

\footnotetext{
${ }^{16}$ It remains an open question whether it would have been better for the overall effectiveness of the mission if the EU had made Tymoshenko's release indispensable for signing the AA. Taking into account the particularly hostile relationship between her and Yanukovych, having her released was seen by many experts as doomed to failure (Interview 1).
} 
to trade off the other. This annoys Russia as much as it does the EU' (Wilson, 2013). In the end, the multi-vector diplomacy in the form of balancing between Russia and the West which Ukraine was pursuing over the last two decades was proven to be wrong. Ukrainian elites decided to rebuff Brussels due to the growing intense pressure from Moscow, but they underestimated the public support for the pro-European orientation of the country. The suspension of the AA/DCFTA aroused protest within Ukrainian society which developed to Euromaidan, a wave of demonstrations in cities all over the country.

Summing up the discussion to what extent the mission managed to fulfil its goals, it has to be mentioned that despite the release of former ministers and the implementation of a few reforms of the judicial system, the special envoys failed in facilitating the release of Tymoshenko. Hence, taking into account the categories introduced at the beginning of the section, the impact of the mission can be seen at the threshold between marginal and considerable. The reforms of the judicial system and the release of political prisoners represent a change in behaviour of the Ukrainian government but the primary goal of the mission was not accomplished.

\section{Conclusions and Discussion}

The main objective of the article was to discuss how the Cox-Kwasniewski mission as an instrument of EP diplomacy shaped EU power in times of crisis in the relationship between Brussels and Kyiv. Drawing on the above-presented analysis of the genesis, development and success level of the mission, there are three aspects of the mission which enabled EU power projection - that is, the promotion of the EU's goals in its relations with Kyiv and managing the crisis in Ukraine.

Firstly, the mission gave the EU some sort of excuse to open the dialogue with Ukraine again. Against the backdrop of the developing crisis between the EU and the Ukrainian government over the negotiations of the AA and the DCFTA and the limited effectiveness of existing ways of exercising EU power, the bilateral relations at the beginning of 2012 were more or less frozen. The EP identified a need to achieve a diplomatic innovation, setting up a mission that would not be directly dependent and restrained by both the Member States and the EU's institutions. In this context, the mission was an expression of the EP's aims to support and contribute to the EU's foreign policy in Ukraine and can be perceived as a product of the constraints and opportunities of the negotiations of the AA. Not tied up with inter-institutional power games over the leadership in the EU policy towards Ukraine, the informal and impartial mission managed to reopen ways of communication between Brussels and Kyiv by holding a dialogue with involved parties. For several months Cox and Kwasniewski were best informed about what was happening in Kyiv and they succeeded in gaining the trust of the Ukrainian government, political prisoners and opposition. Gradually, the mission proved its utility and became the prime spokesperson on behalf of the EU in Ukraine. Due to their activities, Cox and Kwasniewski paved the way for further engagement of the EU after the failure of the Vilnius summit.

Secondly, the mission contributed to enhancing co-ordination between the EU's institutions in dealing with Ukraine, which is crucial for projecting EU power externally. Cox and Kwasniewski maintained close working relations with commissioners Füle and de Gucht, but also with the EP (especially the presidency and the Committee on Foreign 
Affairs). On the ground, in Ukraine, the envoys efficiently shared information and expertise with the delegations of the Member States and the EU. In this way the mission managed to act as an additional bridge between the EP and the Commission or the Member States. Hence, the development and actions of the mission enhanced the level of co-ordination in EU foreign policy, the lack of which has frequently been flagged in literature (Baltag and Smith, 2015; Bicchi, 2014).

Thirdly, even though the mission did not have considerable political impact on the Ukrainian government, the direct and intensive involvement of the EP's envoys accelerated the process of implementation of the pro-European reforms in Ukraine and to some extent prepared the ground for the signing of the AA in 2013. To that extent the mission enabled the projection of EU power, as the EU's main goal in relations with Ukraine during that period was signing the AA. Through very close monitoring of the cases of selective justice and witnessing the deliberations of the Ukrainian parliament, Cox and Kwasniewski exerted indirect (as they had no legal instruments at their disposal) pressure on the government and the President. Thus, the envoys indisputably contributed to the release of three political prisoners and managed to improve prison conditions for Tymoshenko.

Concluding, the mission is a prime example of a diplomatic innovation employed in order to solve an external crisis. It can be seen as a tool that complemented the official efforts of the Commission, the EEAS and the Member States. By having two high-level politicians in charge of the mission, the EP (and the EU for that matter) managed to put a face to its policy in Ukraine. This highlights the ability of the EU to innovate and highlight a high degree of resourcefulness when faced with a developing crisis in relations with Ukraine. At the same time, the mission also reveals the limits of deploying such informal instruments. When the crisis became more severe and transformed into one of security on the European continent (and EU-Russia relations) the EP's role in Ukraine was constrained. Even though Cox and Kwasniewski advocated for their work to be extended during the Maidan protests, the severity of the Ukraine crisis made the EU focus on more high-level approaches by sending initially a mission formed by ministers of foreign affairs and then focusing on negotiations with Russia. The EU approach shifted to high-level diplomacy led primarily by Germany. Hence, the context of a weak external crisis enabled the development of such diplomatic instruments as the Cox-Kwasniewski mission while the emergence of a more acute crisis constrained its further progress as the EU's main mode of engagement.

\section{Correspondence:}

Monika Sus

Hertie School of Governance

Friedrichstraße 180

10117 Berlin

Germany

email: sus@ @ertie-school.org

\section{References}

Adekoya, R. (2014) 'The EU is Going Through a Big Test', Interview with Pat Cox, Warsaw Business Journal Observer, 2 October. Available online at: http://wbj.pl/the-eu-is-goingthrough-a-big-test-interview-with-pat-cox/. Last accessed: 30 December 2015. 
Babayan, N. (2015) 'The Return of the Empire? Russia's Counteraction to Transatlantic Democracy Promotion in Its near Abroad'. Democratization, Vol. 22, No. 3, pp. 438-458.

Baltag, D. and Smith, M. (2015) 'EU and Member State Diplomacies in Moldova and Ukraine: Examining EU Diplomatic Performance Post-Lisbon'. European Integration Online Papers (EIoP), Vol. 19, No. 1, pp. 1-25.

Bicchi, F. (2014) 'Information Exchanges, Diplomatic Networks and the Construction of European Knowledge in European Union Foreign Policy'. Cooperation and Conflict, Vol. 49, No. 2, pp. 239-259.

Casier, T. (2013) 'The EU-Russia Strategic Partnership: Challenging the Normative Argument'. Europe-Asia Studies, Vol. 65, No. 7, pp. 1377-1395.

Council of the European Union (2012) Press Release. 3209th Council Meeting, Foreign Affairs, 10 December. Available online at: www.consilium.europa.eu/uedocs/cms_Data/docs/pressdata/ EN/foraff/134152.pdf. Last accessed: 3 November 2015.

Council of the European Union (2013) Press Release. 3273th Council meeting, Foreign Affairs, 18 and 19 November. Available online at: http://www.consilium.europa.eu/uedocs/cms_data/ docs/pressdata/en/foraff/139633.pdf. Last accessed: 3 November 2015.

Cox P. (2014) 'The Ukrainian Crisis and Geopolitics. An Echo from the Past or the Shape of Things to Come?' Speech at The Institute of International and European Affairs, 23 October. Available online at: www.iiea.com/ftp/Publications/The\%20Ukrainian\%20Crisis\%20and\% 20Geopolitics_An\%20echo\%20from\%20the \%20past $\% 20$ or $\% 20$ the $\% 20$ shape $\% 20$ of $\% 20$ things $\% 20$ to\%20come_Pat\%20Cox_IIEA-2014.pdf. Last accessed: 28 December 2015.

David, M., Gower, J. and Haukkala, H. (eds) (2013) National Perspectives on Russia: European Foreign Policy in the Making? (London: Routledge).

Delcour, L. and Wolczuk, K. (2015) 'Spoiler or Facilitator of Democratization? Russia's Role in Georgia and Ukraine'. Democratization, Vol. 22, No. 3, pp. 459-478.

European Parliament (2013) Press Release. Cox-Kwaśniewski Monitoring Mission to Ukraine Extended, 18 April. Available online at: www.europarl.europa.eu/former_ep_presidents/president-schulz/en/press/press_release_speeches/press_release/2013/2013-april/html/cox-kwaniewski-monitoring-mission-to-ukraine-extended. Last accessed: 1 November 2015.

European Parliament Monitoring Mission to Ukraine (2013a) Mission Update, 18 April. Available online at: www.europarl.europa.eu/former_ep_presidents/president-schulz/resource/static/files/ ep-monitoring-mission-assessment--17.04.pdf. Last accessed: 22 November 2015.

European Parliament Monitoring Mission to Ukraine (2013b) Key Observations to the Conference of Presidents of the European Parliament, 15 October. Available online at: www.europarl.europa.eu/former_ep_presidents/president-schulz/en/press/press_release_speeches/press_release/ 2013/2013-october/pdf/ep-monitoring-mission-to-ukraine--key-observations-to-the-conferenceof-presidents-of-the-european-parliament/. Last accessed: 3 November 2015.

European Parliament Monitoring Mission to Ukraine (2013c) Mission Statement, 13 November. Available online at: www.europarl.europa.eu/former_ep_presidents/president-schulz/en-fa/ press/press_release_speeches/press_release/2013/2013-november/html/european-parliamentmonitoring-mission-to-ukraine--mission-statement /. Last accessed: 1 November 2015.

European Union (2013) Joint Statement by the EU High Representative, Catherine Ashton, and Commissioner Stefan Füle on the Pardoning of Yuriy Lutsenko, 7 April. Available online at: www.consilium.europa.eu/uedocs/cms_Data/docs/pressdata/EN/foraff/136668.pdf. Last accessed: 15 November 2015.

Fierke, K.M. and Jorgensen, K.E. (2015) Constructing International Relations: The Next Generation (Abingdon: Routledge).

Fiott, D. (2011) 'On the Value of Parliamentary Diplomacy'. Madariaga Paper, Vol. 4, No. 7. Available online at: http://www.madariaga.org/images/madariagapapers/2011-apr-fiott-on\% 20the\%20value\%20of\%20parliamentary\%20diplomacy.pdf. Last accessed: 27 July 2016. 
Freire, M.R. (2014) 'Russian Reactions towards EU-Black Sea Integration'. Journal of Balkan and Near Eastern Studies, Vol. 16, No. 3, pp. 370-382.

Ginsberg, R.H. (2001) The European Union in International Politics (Maryland: Rowman and Littlefield).

Gnedina, E. (2015) “Multi-Vector” Foreign Policies in Europe: Balancing, Bandwagoning or Bargaining?' Europe-Asia Studies, Vol. 67, No. 7, pp. 1007-1029.

Griffiths, M. (ed.) (2007) International Relations Theory for the Twenty-First Century: An Introduction (Abingdon: Routledge).

Gotev, G. (2013) 'Suspense grows in EU-Ukraine gamble'. Euroactive, 17 October. Available online at: www.euractiv.com/europes-east/suspense-grows-eu-ukraine-gamble-news-531131. Last accessed: 4 November 2015.

Haukkala, H. (2010) 'Explaining Russian Reactions to the European Neighbourhood Policy'. In Whitman, R.G. and Wolff, S. (eds) The European Neighbourhood Policy in Perspective: Context, Implementation and Impact (London: Palgrave Macmillan), 161-178.

Petrova T. (2014) 'Polish Democracy Promotion in Ukraine'. Carnegie Endowment for International Peace, Washington, DC. Available online at: carnegieendowment.org/files/ RDN_Petrova_Ukraine.pdf. Last accessed: 8 November 2015.

Pifer, S. (2007) 'Ukraine Looks West. European Mediators and Ukrainian's Orange Revolution'. Problems of Post-Communism, Vol. 54, No. 6, pp. 28-42.

Puhl, J. and Neef, C. (2013) 'Ex Polish Leader on Failed Ukraine Talks', Spiegel Online, 12 Febuary. Available online at: http://www.spiegel.de/international/europe/spiegel-interviewwith-aleksander-kwasniewski-on-ukraine-talks-a-937964.html. Last accessed: 1 October 2015.

Rettman, A. (2012) 'Ukraine firms up promise on Tymoshenko monitoring'. EUObserver, 22 May. Available online at: euobserver.com/foreign/116339. Last accessed: 10 November 2015.

Samokhvalov, V. (2015) 'Ukraine between Russia and the European Union: Triangle Revisited'. Europe-Asia Studies, Vol. 67, No. 9, pp. 1371-1393.

Servent, A.R. (2015) Institutional and Policy Change in the European Parliament: Deciding on Freedom, Security and Justice (Basingstoke: Palgrave Macmillan).

Sinkkonen, T. (2011) 'A Security Dilemma on the Boundary Line: An EU Perspective to Georgian-Russian Confrontation after the 2008 War'. Southeast European and Black Sea Studies, Vol. 11, No. 3, pp. 265-278.

Smith, N.R. (2015) 'The EU and Russia's Conflicting Regime Preferences in Ukraine: Assessing Regime Promotion Strategies in the Scope of the Ukraine Crisis'. European Security, Vol. 24, No. 40, pp. 1-16.

Stavridis, S. and Irerra, D. (eds) (2015) The European Parliament and Its International Relations (Abingdon: Routledge).

Weisglas, F.W. and de Boer, G. (2007) 'Parliamentary Diplomacy'. The Hague Journal of Diplomacy, Vol. 2, No. 40, pp. 93-99.

Wilson, A. (2014) Ukraine Crisis: What It Meansfor the West(New Haven, CT: Yale University Press).

\section{Interviews}

Interview with a think-tank expert, Warsaw, 10 November 2015 (Interview 1).

Interview with a staff member of Kwasniewski office, Warsaw, 10 November 2015 (Interview 2).

Interview with EEAS official, via phone, 4 December 2015 (Interview 3).

Interview with President Aleksander Kwasniewski, Warsaw, 8 December 2015 (Interview 4, conducted on author's behalf by B. Rydlinski, staff member of President's office). Interview with EEAS official, Berlin, 9 December 2015 (Interview 5). 